\title{
Does the Teaching and Learning Process in Primary Schools Correspond to the Characteristics of the 21st Century Learning?
}

\section{Lalu Sumardi}

Ph.D., correspondent author, Faculty of Teacher Training and Education, University of Mataram, Indonesia, lalu.unram@gmail.com

\section{Arif Rohman}

Assoc. Prof., Universitas Negeri Yogyakarta, Indonesia, arif_rohman@uny.ac.id

\section{Dwi Wahyudiati}

Asst. Prof., Universitas Islam Negeri Mataram, Mataram, Indonesia, dwiwahyudiati@uinmataram.ac.id
This paper sheds some light on the extent to which the teaching and learning process in the primary school context has met the characteristics of 21 st-century learning, and factors affecting it. This case study research garnered the data from 120 elementary school teachers of 40 primary schools, 20 of which were municipal primary schools, while the other half were peripheral. The data, collected through observation and interview, were analyzed using the interactive model and quantitatively descriptively presented. The empirical evidence showed that the process of teaching and learning performed by more than half of the primary school teachers did not feature the 21st century learning. Most of the instruction adopting teacher-centered learning $(59,17 \%)$, use of conventional methods (59.17\%) resulting in less development of students' high-order thinking (HOT), the absence use of technologies in teaching and learning (100\%), and disconfirm of students' learning development at primary level $(53,33 \%)$. However, the teachers were found to have some strength in terms of content mastery $(95 \%)$ who could explicitly and completely deliver the materials in the class. The absence of the digital infrastructure in the schools and lack of pedagogical and technological knowledge and understanding of students' development remained the challenges in catering to the characteristics of 21 st century learning in the classrooms. The implication of this condition is that students in Indonesia lag behind other countries in mastering science and technology.

Keywords: primary schools, 21 st century learning, teacher competence, ICT, learning

Citation: Sumardi, L., Rohman, A., \& Wahyudiati, D. (2020). Does the Teaching and Learning Process in Primary Schools Correspond to the Characteristics of the 21st Century Learning? International Journal of Instruction, 13(3), 357-370. https://doi.org/10.29333/iji.2020.13325a 


\section{INTRODUCTION}

The $21^{\text {st }}$ century is known as the digital age, where all sectors, including education, should be digitalized, and in which technologies play a fundamental role in education (Henrisken et al., 2016; Sumardi, Rispawati, \& Ismail, 2017). For this reason, educational development should be oriented towards the use of ICT (Information Communication and Technology) as the management system in this century (Soderstorm et al., 2011). Education should integrate ICT in its process unless it will experience a setback, not to mention a failure (Dass, 2014). Similarly, teachers should revitalize their basic pedagogical practices, from instructional theories to practices. Hashim (2014) opines that the theoretical basis of the teaching and learning in the $21^{\text {st }}$ century does not only underlie "constructivism" but also "connectivism" philosophy of learning, where students are connected through digital media. Likewise, in its practice, the approach and paradigm of teaching and learning have shifted from student-centered learning to student-self direct learning (Hashim, 2014; Sumardi, 2014: Fadli, 2020), the students seek for the knowledge not transferred (Ismail, 2017; Wijaya et al., 2016). Students look for information from various resources through the use of ICT as it enables them to access to a wide array of information at anytime and anywhere (Hellebrandt, 1996; Wijaya et al., 2016).

ICT has yielded profound effects on the teaching and learning for both the teachers and students (Ghavifekr \& Rosdy, 2015), and afforded the opportunity to create creative and effective learning (Oxana \& Moeller, 2012). ICT also benefits and provides chances for the students to access unlimited amount of information rapidly (Hellebrandt, 1996), builds networking and communication that enable them learn at their own pace (Moore, 2006), and emboldens them to be more creative, active, and not reliant on the texts (Oxana \& Moeller, 2012; Ghavifekr \& Rosdy, 2015). Hence, ICT transforms the process of teaching and learning from teacher-centered to student-centered learning (Jan, 217), which has direct impacts on the effectiveness of the pedagogical practices (Ghavifekr \& Rosdy, 2015).

The learning paradigm of the $21^{\text {st }}$ century leads to the development of students' competence, such as critical thinking, communication, collaboration, creative thinking, and innovation (Sharon \& Kay, 2010; Ismail, 2017), metacognition, information literacy and ICT, civic (Suto, 2013), and problem-solving, which Trilling and Fadel (2009) coin as creativity and innovation of learning. In addition, the most important aspect of learning that $21^{\text {st }}$ century learning focuses on is a collaboration, one of the most essential objectives of education (Child, 2016), in that it is the key to learn in this century (Ginsburg-Block, 2006). Additionally, collaboration has positive impacts on students' learning and memories (Fall et al., 1997; Saner et al., 1994), and on their capability of applying the knowledge and skills necessary in their social (OECD, 2013). All the aforementioned objectives learning are aimed to attain the ones constructed by UNESCO, namely "learning to know, learning to do, learning to be, and learning to live together" (Diptoadi, 1999).

Digital infrastructure along with resilient teachers should be promoted in order to successfully operate the teaching and learning based ICT and to attain the intended 
learning outcomes. Resilient teachers are the ones having a strong desire, determination, energy, knowledge and moral strength (Day \& Gu, 2014). Highly competent teachers are of paramount importance in the teaching and learning because teacher quality is the most significant and determining factor for the success of pedagogical practices in the classroom (Rozdi et al., 2016; Blomeke et al., 2016).

Teachers required in the $21^{\text {st }}$ century are those who possess the competence, qualification, and knowledge about teaching and learning. This is due to the different roles that the teachers recently have, namely teachers as student task designers, facilitators of learning, mentors (Reigeluth, 2017), knowledge mediator, and key person who performs and innovates the process learning (Panev \& Barakoska, 2015). Among the demanded competence that the teachers need to acquire nowadays are teaching competence, technological competence, professional competence and learning competence (Pineida, 2011).

In the Indonesian context, the government especially the national education ministry responds to the rapid development of ICT with the modernization of education. The Indonesian Ministry of Education since 2006 has made improvements in all aspects of education, such as the curriculum, education infrastructure, and teacher quality. The question is whether the efforts made so far had fulfilled the needs of ICT infrastructure in schools, especially in primary schools? Has the effort made so far been successful in increasing the competence of elementary school teachers in conducting teaching and learning processes that are in accordance with the characteristics of $21^{\text {st }}$ century education? This paper will reveal these two questions clearly.

This paper aims to reveal whether the teaching and learning process in elementary schools in East Lombok, West Nusa Tenggara Province correspond to the characteristics of $21^{\text {st }}$ century learning or not and the factors that influence it. These findings of the research are expected to contribute to improving the quality of teaching and learning in elementary schools, especially in East Lombok, West Nusa Tenggara Province, Indonesia.

\section{CONTEXT AND LITERATURE REVIEW}

With the current rapid development of ICT use in education, teachers with better technological competence are required (Wahyudiati, Rohaeti, Irwanto, Wiyarsi, \& Sumardi, 2020). The characteristics of the $21^{\text {st }}$ century teachers according to Najri (2014) are those who have competence in the use of technologies, good pedagogical knowledge, general knowledge, positive attitudes, a good understanding of curriculum and psychology of learning. The Indonesia Ministry of Education (2013) stipulates that $21^{\text {st }}$ century teachers are the ones who have professional, pedagogical, social and personal competences.

In this digital age, teachers remain the determining factors for the process of teaching and learning because they play central roles in the quality of the pedagogical process (Jan, 2017). These teachers with higher levels of intellectual, social and emotional competence will be able to successfully carry out the teaching and learning process because they are more resilient (Day \& Gu, 2014). 
Brunner (1976) states that among the many competences a teacher oughts to have are being able to design a systematic lesson plan, apply a collaborative approach with the students, avoid the use of the rigid methods, and implement collaborative learning methods. Among the many $21^{\text {st }}$ century teaching methods that can be applied is the "inquiry method" (Ginsburg-Block, 2006), problem-solving (Wijaya et al., 2016; Fadli, 2020), and question and answer method (Diptoadi, 1999). To be able to successfully carry out the teaching and learning, a teacher should have some basic competences, namely critical thinking, creativity and innovation (Norahmi, 2017; Tyas, 2017). These basic competencies of critical thinking are needed for the teachers to be able to establish smart social networking (Boholono, 2017; Sumardi, Rispawati, \& Ismail, 2017).

What is more, two principles of the $21^{\text {st }}$ century learning that should be capitalized on, namely learning as a "generic approach to learning", in which the students seek and construct their own knowledge (Benade et al., 2014). Teachers only play roles as a mediator of learning (Panev \& Barakoska, 2015), facilitator, and effective guide (Guzey \& Roehrig, 2012). Secondly, learning requires "corporating knowledge and doing", where knowledge is learned and practiced in the real-world to create meaningful learning. For the same token, Jan (2017) presents eight characteristics of the $21^{\text {st }}$ century learning, namely student and individual-centered learning, students as producers, project-based learning, learning new technologies, go global, smart at using ICT, collaborative and innovative.

Also, Garcia \& Morrel (2013) state that the key feature of the $21^{\text {st }}$ century learning is the digitalization of the teaching and learning process as technologies remain an important component in the classroom for the teachers to create extraordinary learning (Boholono, 2017). Digital technologies encourage students' participation and collaboration between teachers and facilitate and guide students' to learn independently as well as afford the teachers an opportunity to create various creative instructional strategies. Some empirical evidence shows that the use of technologies in learning has the potential to elevate and promote interactive learning (Parvin \& Salam, 2015). ICT, according to Peneida (2011), is a powerful tool for the teachers to improve the teaching and learning quality if implemented perfectly. Therefore, the teachers are demanded to be competent in operating ICT and should integrate it into the classroom (Boholono, 2017). Plomp et al. (2009) state that every teacher should be proficient at using ICT in learning, which may indicate the development of the teaching and learning process.

From the above explanation, it can be formulated four main characteristics of $21^{\text {st }}$ century teaching and learning, namely; (1) student-centered learning, (2) using learning methods that encourage collaboration between students and build their own knowledge, (3) involve technology in teaching and learning, and (4) completeness in learning material. These four characteristics are the references in this study to answer the research question of whether the teaching and learning process carried out by elementary school teachers in East Lombok corresponds to the characteristics of $21^{\text {st }}$ century education or not.

Furthermore, some research findings also show that the quality of teaching and learning is affected by several factors. Blomeke et al. (2016) unveiled three factors affecting the 
quality of teaching and learning, namely teacher quality, teacher pedagogical experience, and teacher professional development program. Teacher quality is strongly correspondent to two things, such as content mastery and pedagogical competence (Clotfelter, 2007). Additionally, Gustafson \& Nilsen (2016) found that students' learning outcomes are determined by two factors, namely teacher education level, and professional development, while teachers' experience and self-efficacy do not have significant effects on the learning. Theoretically, motivation and students' learning outcomes are influenced by the quality of the teaching and learning, the latter is then determined by the teacher quality, while the teacher quality is determined by their education and teaching experience, professional training program and teacher competence (Scherer \& Nilsen, 2016).

\section{METHOD}

\section{The Study}

The research approach used in this study is a naturalistic approach and one type of it's a case study (Bogdan \& Biklen, 2007; 223). Case studies are research strategies where researchers carefully investigate a program, event, activity, process, or study a group of individuals (Creswell, 2009; Sumardi \& Hanum, 2019). The current study looked into the process of teaching and learning carried out by primary school teachers, whether or not it has conformed with the characteristics or principles of the $21^{\text {st }}$ century learning, and uncovered the factors affecting the process.

The data pertinent to the pedagogical process are only based on four indicators, namely learning approach (teacher-centered or student-centered learning), the teaching methods used (oriented to the development of critical thinking, problem-solving students' collaboration, and contextualization), the use of instructional technologies, and content mastery (taught clearly and completely).

\section{Source of Data}

The data source of this research is elementary school teachers in East Lombok, West Nusa Tenggara, Indonesia. The sampling technique used was purposive sampling. Based on the purposive technique, the researchers chose 40 primary schools as research units, 20 primary schools located in municipal areas and 20 in peripheral areas. The number of data sources from each school is three teachers. The total numbers of samples were 120 people. The details are given in the table beneath:

Table 1

The Geographical Distribution of Data Sources

\begin{tabular}{llll}
\hline Location & No. of School & No. of Subject & $\%$ \\
\hline Municipal Primary Schools & 20 & 60 & 50 \\
\hline Peripheral Primary Schools & 20 & 60 & 50 \\
\hline Total & 40 & 120 & 100 \\
\hline
\end{tabular}




\section{Techniques and Instruments of Data collection}

The data were garnered in two ways, namely observation and interview. The observation was applied to collect the data from the teaching and learning process performed by the teachers in the class. Observations were made at least twice for each data source and were made on different days. If the second observation of the data felt saturated then the data collection was stopped. While the interview is conducted shortly after learning is done. Thus events that are seen in the learning process can be clarified immediately.

The data collected by observation are included the ones regarding the approach, method, and completeness of the material taught by the teacher. Whereas, the interview was used to collect the data related to the teachers' understanding of students' development, learning approach, strategy, and method, ICT mastery, and the technological infrastructure owned by the schools.

With regard to the instruments used in collecting the data through observation, structured guideline observation was applied, while semi open-ended question was used to collect the data through an interview (Creswell, 2009). Both of these instruments were used in this study.

\section{Data Analysis Techniques}

The garnered data were analyzed using an interactive model coined by Miles, Huberman, \& Saldana. The interactive analysis model is the process of data analysis carried out since researchers begin to collect data before the report is formulated (Emzir, 2012; 131). During this time the data was compiled and updated based on observations and interviews conducted.

The interactive analysis model comprises three stages, namely data reduction, presentation and conclusion or verification (Miles, Huberman, and Saldana, 2014). The first stage includes the process of selecting, focusing on, simplifying, abstracting, and transcribing the data. From the analysis process, findings can be categorized based on $21^{\text {st }}$ century education characteristics and types of data. The next step is the presentation of data consisting of organizing, summarizing, comparing the data with the theories or principles of the $21^{\text {st }}$ century learning, and presenting the data. Data display is done quantitatively, i.e. in the form of numbers that are tabulated (quantifying data). Data comparison was performed especially for the research question no. 1. The final stage of the data analysis was interpreting or concluding the empirical evidence.

\section{FINDINGS}

The empirical findings were related to two things, namely the implementation process of teaching and learning in the class, whether it has corresponded to the characteristics of the $21^{\text {st }}$ century learning or not. The indicators used to measure this were the instructional approach used (student-centered learning), instructional method (oriented to the development of critical thinking, problem-solving, students' collaboration, and contextualization), the use of ICT in learning, and content mastery of the teachers 
(taught explicitly and completely). Secondly, what factors affected the teaching and learning process.

Based on the above observation indicators, it's known that the teaching and learning process in primary schools could be illustrated in the table below;

Table 2

Implementation of Teaching and Learning

\begin{tabular}{llllll}
\hline \multirow{2}{*}{ No } & Aspek & Yes & \multicolumn{3}{l}{ No } \\
\cline { 3 - 6 } & & $f$ & $\%$ & $f$ & $\%$ \\
\hline 1 & $\begin{array}{l}\text { The instructional approach used (student- } \\
\text { centered lerning) }\end{array}$ & 49 & 40.83 & 71 & 59.17 \\
\hline 2 & $\begin{array}{l}\text { Instructional method (oriented to the } \\
\text { development of critical thinking, problem } \\
\text { solving, students' collaboration, and } \\
\text { contextualization) }\end{array}$ & 49 & 40.83 & 71 & 59.17 \\
\hline 3 & The use of ICT in learning & 0 & 0 & 120 & 100 \\
\hline 4 & Content mastery (explicit and complete) & 114 & 95 & 6 & 5 \\
\hline
\end{tabular}

The table above portrays that $59,17 \%$ of the primary school teachers carried out the process of teaching and learning with teacher-centered learning, while only $40.83 \%$ of who deployed student-centered learning approach. With respect to the instructional method, $59.17 \%$ of the teachers used conventional methods (lecture, take notes), while $40.83 \%$ of them employed the methods oriented towards the development of high order thinking. This includes the use of the inquiry method, role plying method, and experiment methods. Regarding the use of ICT in learning, none of these teachers in the study made use of existing technologies in teaching. On the other hand, $95 \%$ of the teachers acquired the content and explicitly and completely taught to the students.

From the interviews, it's known that there are several reasons why teaching and learning conducted is far from the characteristics of $21^{\text {st }}$ century teaching as shown in the table below;

Table 3

Factors Affecting the Teaching and Learning Process Conducted by Teachers

\begin{tabular}{llllll}
\hline NO & \multicolumn{1}{c}{ Influential Faktors } & \multicolumn{3}{c}{ Yes } & \multicolumn{2}{c}{ No } & \% \\
\cline { 3 - 6 } & Teachers' knowledge about the various & 60 & 50 & 60 & 50 \\
\hline 1 & $\begin{array}{l}\text { Teaching methods } \\
\text { teachers' understanding about the students' } \\
\text { development }\end{array}$ & 56 & 46.67 & 64 & 53.3 \\
\hline 3 & $\begin{array}{l}\text { Teachers' ability to operate the ICT (laptop } \\
\text { and LCD) }\end{array}$ & 12 & 10 & 108 & 90 \\
\hline 4 & $\begin{array}{l}\text { The availability of the ICT infrastructure at } \\
\text { schools (laptop, LCD, and internet access) }\end{array}$ & 1 & 2.5 & 39 & 97.5 \\
\hline
\end{tabular}

The results of the interview show as the table above that $50 \%$ of the primary school teachers possessed adequate knowledge about the teaching methods, while half of them were less likely to have sufficient knowledge in the domain. With regard to their 
understanding of the students' development, $53.33 \%$ of the teachers did not have adequate understanding about it, while $46.67 \%$ of who were otherwise. Regarding the ability to use ICT (leptop and LCD), 90\% of these teachers were not competent enough in operating ICT, and only $10 \%$ were proficient enough. It can also be seen that $97.5 \%$ of the schools did not have ICT infrastructure, while $2.5 \%$ of them were completed with it.

\section{DISCUSSION}

Research findings show that there are still more teachers (59.17\%) in East Lombok who teach using the teacher-centered approach and use conventional methods (lecturing, and taking notes). This means there are still many teachers who do learning not in accordance with the characteristics of $21^{\text {st }}$ century learning. This finding corresponds to the study conducted by Diptoadi (1999) and Sumardi $(2008 ; 2012)$ who unveiled that teaching and learning in Indonesia mostly carried out using traditional methods and focuses more on memorization. In the 21 st century teachers should carry out teaching and learning in accordance with the demands of $21^{\text {st }}$ century learning. The main characteristics of $21^{\text {st }}$ century learning are student-centered learning, using learning methods that emphasize collaboration and build own knowledge, and the use of ICT.

Student-centered learning according to Wijaya (2016) automatically emphasizes collaborative learning and encourages students to construct their own knowledge. Collaboration in the 21 st century according to Child (2016) is an important education outcome more than just knowledge. This is important for the development of the students' knowledge and skills in real life and is very crucial in future work (OECD, 2013).

Drawing on research findings, half of the teachers in this should ideally be able to carry out the process of teaching and learning that center on the students and the development of their high-order thinking skills (HOT) because this study shows that half the teachers $(50 \%)$ had sufficient understanding about the use of various teaching and learning methods. This is in line with the opinion expressed by Arend (2014) that teachers who have a sufficient understanding of learning will do learning well. A study conducted by Blomeke, at al. (2016) on PISA at involving 47 countries also unveiled that the pedagogical competence of the teachers was significantly correspondent to the quality of teaching and learning process and students' learning outcomes. The teachers who have adequate pedagogical skills can promote the quality of the teaching and learning process and improve students' learning outcomes. This is because the learning quality is a variable that directly corresponds to the students' academic achievements (Scherer dan Nilsen, 2016).

The use of incompatible approaches and methods with the characteristics of 21stcentury learning is caused by the lack of understanding of the teachers about the students' development. The current study evidenced that more than half of the teachers do not have a good understanding of the cognitive, social and moral development of their students. This may adversely impact the misuse of teaching approaches and methods. Slavin (2000) and Sagala (2009) advocate that it is incumbent on the teachers 
to understand the characteristics of their students in order to be able to choose appropriate materials and teaching methods that correspond to the development, experience, and need of the students.

As for those related to the integration of ICT in teaching and learning, Jan (2017) revealed that technology is a key instrument to improve the quality standards of student learning. With technology, students can access a variety of information anywhere at any time at their own pace and can create meaningful learning activities (Hellebrandt, 1996). Due to its crucial role, the technological infrastructure should be available at every school, and each teacher should have the necessary skills to operate them. However, this study found that none of the teachers in the study employed ICT in the teaching and learning process. This is because the schools do not have adequate digital infrastructures, such as laptops, LCD, and internet access. Likewise, the majority of the primary school teachers are not proficient in the operation of technologies (laptop, LCD). This empirical evidence demonstrates that the pedagogical practices at the primary school level do not feature the $21^{\text {st }}$ century learning. Such a condition, of course, adversely impacts on the quality of the teaching and learning process and the students' learning outcomes given other empirical evidence encapsulating the correlation between the use of ICT and the quality of the teaching and learning process and students' academic attainments (Levy, 2009; Oxana dan Meller, 2012; Ghavifekr \& Rosdy, 2015).

Despite this, research findings show that the process of teaching and learning at the primary school has some strengths, namely the explicit and complete instruction. This shows that the teachers acquire the subjects being taught, which may become the main capital to create a high quality learning environment. The mastery of the learning materials for the teachers, according to Slavin (2000), is tremendously important because this is one of the characteristics of good teachers. In addition, content mastery has been found to correlate significantly to the students' learning outcomes. If the teachers have adequate content mastery, the students' academic achievements will be better (Blomeke, 2016).

\section{CONCLUSION}

This study examines the teaching and learning process carried out by elementary school teachers in East Lombok, West Nusa Tenggara, Indonesia whether it corresponds to the characteristics of $21^{\text {st }}$ century learning or not and what factors influence it. For the first problem statement, there are four aspects assessed to find out whether the teaching and learning conducted by teachers correspond or not to the characteristics of $21^{\text {st }}$ century learning, namely; approaches, methods, integration of ICT in learning, and completeness in learning material.

Based on the items above this study encapsulates that the teaching and learning process at the primary school level does not correspond to the key features of twenty-firstcentury learning. It does not represent the real practice of the current pedagogical practices. The factors affecting this phenomenon is the lack of teachers' competence in operating ICT, the absence of technological infrastructure at the schools, inadequate 
knowledge of the teachers about various teaching methods, and their lack of understanding on the students' development and the ideal instruction that is suited to the way students learn.

\section{RECOMMENDATION}

Based on the findings and discussion above, it is of paramount importance for the government to revitalize the education sector, particularly on primary school level through the development of digital infrastructure and teachers' pedagogical and technological competence, which can be catered through a structured teacher professional development program. So, the recommendations of this study are; the government must equip information and technology infrastructure for all schools and improve the ability of teachers and education personnel through planned and continuous training.

Because this study is a case study in nature, which may lack a rigour in terms of the data collection as it relies on a few classroom observations, future research may look at more complex issues using quantitative or more in-depth qualitative study, such as ethnography, correlational survey research, that look into the teaching and learning practices of the primary school teachers over a period of time. Another study may also be essential to carry out in a different education level, such as secondary or university levels.

\section{REFERENCES}

Arends, R. (2001). Learning to teach. New York: McGraw-Hill Companies.

Benade, L., Gardner, M., Tescher, C., \& Gibbons, A. (2014). 21 ${ }^{\text {st }}$ century learning in New Zealand: Leadership insights and perspectives. Journal of Educational Leadership Policy and Practice, 29 (4), 47-60.

Blomeke, S., Olsen, R. V., \& Suhl, U. (2016). "Relation of student achievement to the quality of their teachers an instructional quality". In T. Nilsen, \& J-E. Gustafsson (Eds.), Teaching quality, instructional quality and student outcome: Relationships across countries, cohorts and time. (pp. 21-50). Sweden: Springer.

Bogdan, C. R., \& Biklen, S. K. (2007). Qualitative research for education: An introduction to theories and methods. USA: Person Education, Inc.

Boholono, H. B. (2017). Smart social networking: $21^{\text {st }}$ century teaching and learning skills. Research in Pedagogy, 7(1), 21-29.

Child, S. (2016). Collaboration in the $21^{\text {st }}$ century: Implication for assessment. Research Matters, 22, 17-22.

Clotfelter, C. H., Ladd, H., \& Vigdor, J. (2007). Teachers credential and student achievement: Longitudinal analysis with student fixed effect. Economic of Education Review, 26, 673-682. 
Creswell, J. W. (2009). Research design: Qualitative, quantitative, and mixed methods approaches. Thousand Oaks California: SAGE Publications.

Dass, R. (2014). Literature and the $21^{\text {st }}$ century learner. Procedia-Social an Behavioral Sciences, 123, 289-298.

Day, C., \& Gu, Q. (2014). Resilient teachers, resilient schools: Building and sustaining quality in testing times. New York: Routledge.

Diptoadi, V. L. (1999). Educational reform in Indonesia faces the challenges of the 21st century. Jurnal Ilmu Pendidikan, 6(3), 162-175.

Emzir. (2012). Qualitative research methodology: Data analysis. Jakarta: Rajawali Pers.

Fadli, A. (2019). Problem solving skills and scientific attitudes of prospective teachers based on gender and grades level. International Journal of Scientific \& Technology Research, 8(10), 3595-3599.

Fadli, A., \& Irwanto. (2020). The Effect of Local Wisdom-Based ELSII Learning Model on the Problem Solving and Communication Skills of Pre-Service Islamic Teachers. International Journal of Instruction, 13(1), 731-746.

Fall, R., Webb, N., \& Chudowsky, N. (1997). Group discussion and large-scale language arts assessment: Effects on students' comprehension. CSE Technical Report 445. Los Angeles: CRESST.

Garcia, A., \& Morrel, E. (2013). City youth and the pedagogy of participatory media. Learning, Media and Technology, 38(2), 123-127.

Ghavifekr, S., \& Rosdy, W. A. W. (2015). Teaching and learning with technology: Effectiveness of ICT integration in schools. In J of Res in Edu and Sci, 1 (2), 175-191.

Ginsburg-Block, M. D., Rohrbeck, C. A., \& Fantuzzo, J. W. (2006). A meta-analytic review of social, self-concept, and behavioral outcomes of peer-assisted learning. Journal of Educational Psychology, 98(4), 732-749.

Gustafson, J. E., \& Nilsen, T. (2016). "The impact of school climate and teacher quality on Mathematics achievement: A difference-in-differences approach". In T. Nilsen, \& JE. Gustafsson (Eds.), Teaching quality, instructional quality and student outcome: Relationships across countries, cohorts and time (pp. 81-96). Sweden: Springer.

Guzey, S. S., \& Roehrig, G. H. (2012). Integrating educational technology into the secondary science teaching. Contemporary Issue in Tec and Teac Edu, 12(2), 162-183.

Hashim, Y. (2014). $21^{\text {st }}$ century education: Are we heading toward the right direction of improving and learning as needed by educational transformation frogramme? Retrieved from https://www.researchgate.net/publication/. 
Hellebrandt, J. (1996). Multimedia and foreign language teacher: A humanistic perspective. In Z. Moore (Eds.), Foreign language teacher education: Multiple perspectives (pp. 33-50). Maryland: University Press of America.

Henrisken, D., Mishra, P., \& Fisser, D. (2016). Infusing creativity and technology in $21^{\text {st }}$ century education: A systematic view of change. Edu Tec \& Society, 19(3), 27-37.

Ismail, A. I. (2017). Questioning $21^{\text {st }}$ century competence. Retrieved from http://mediaindonesia.com/read/detail/126180.

Jan, H. (2017). Teacher of $21^{\text {st }}$ century: Characteristics and development. Research on Humanities and Social Sciences, 7(9), 50-54.

Kobalia, K., \& Garakanidze, E. (2010). The professional competencies of the $21^{\text {st }}$ century school teacher. Problem of Education in The $21^{\text {st }}$ Century, 20, 104-108.

Levy, M. (2009). Technologies in use for second language learning. The Modern Language Journal, 93, 769-782.

Miles, M. B., Huberman, M., \& Saldana. (1994). Qualitative data analysis: A methods sourcebook. USA: SAGE Publication.

Najri (2014). The decision of the Sultan Idris Education University of Malaysia regarding the management of schools to deal with the implementation of 21 st century education. Retrevied from http://www.academia.edu.

Norahmi, M. (2017). $21^{\text {st }}$ century teachers: The studens' perspectives. Journal of English as a Foreign Language, 7 (1), 77-96.

OECD. (2013). Programme for International Student Assessment (PISA) 2015: Draft collaborative problem solving framework. Paris: OECD.

Oxana, D., \& Moeller, A. K. (2012). Teaching culture in the $21^{\text {st }}$ century language classroom. Retrieved from http://digitalcommons.unl.edu/teachlearnfacbub/181.

Panev, M. A. F., \& Barakoska, A. (2015). The need of strengthening the pedagogical competencies in teaching from the English teachers' perspective. International Journal of Cognitive Research in Science Engineering on Education, 3(1), 43-50.

Parvin, R. H., \& Salam, S. F. (2015). The effectiveness of using technology in English language classrooms in government primary schools in Bangladesh. FIRE: Forum for International Research in Education, 2(1), 47-59.

Pineida, F. O. (2011). Competencies for $21^{\text {st }}$ century: Integrating ICT to life, school and economical development. Procedia-Social and Behavioral Science, 28, 54-57.

Plomp, T., Andersen, R., Law, N., \& Quale, A. (2009). Cross-national information and communication technology: Policies and practices in education. N Carolina: IEA- IAP.

Reigeluth, C. M., Myers, R. D., \& Lee, D. (2017). The learner centered paradigm of education. In M. R. Charles, J. B. Brian, \& D. M. Rodney (Eds.), Instructional-design 
theories and models: The learner-centered paradigm of education (pp. 15-34). New York: Routletge.

Rozdi, Z. M., Ahmad, C. N. C., \& Mohamed, Z. (2016). Competency model of science teacher in $21^{\text {st }}$ century. Int $J$ of Academic Res in Business and Soc Sci, 6(12), 33-38.

Saner, H., McCaffrey, D., Stecher, B., Klein, S., \& Bell, R. (1994). The effects of working in pairs in science performance assessments. Educational Assessment, 2(4), $325-338$.

Scherer, R., \& Nilsen, T. (2016). The relation among school climate, instructional quality and achievement motivation in Mathematics. In T. Nilsen, \& J-E. Gustafsson (Eds.), Teaching quality, instructional quality and student outcome: Relationships across countries, cohorts and time (pp. 51-80). Sweden: Springer.

Slavin, R. (2000). Educational psychology theory and practice. USA: By Allyn \& Bacon.

Soederstorm, T., From, J., Lovqvist, J., \& Tomquist, A. (2011). From distance to online education: Educational management in the $21^{\text {st }}$ century. Annual Conference Dublin.

Sumardi, L. (2008). Analisis pelaksanaan pembelajaran PPKn di sekolah dasar kelas rendah (studi kasus di Mataram) [Analysis of the implementation of Civics Education teaching and learning in low grade primary schools (case study in Mataram)]. Thesis. Retrieved from https://scholar.google.com/scholar?.

Sumardi, L. (2012). The revitalization of social sciences teaching in elementary school as an effort to create students who have good character. SOCIA: Jurnal Ilmu-Ilmu Sosial, 11(2), 157-164.

Sumardi, L. (2014). Telaah rencana program pembelajaran Pendidikan Pancasila dan Kewarganegaraan sekolah dasar di Kota Mataram [Anlysis of the planning program of civic education for elementary education in Mataram city]. EL-HIKAM, VII(2), 309324.

Sumardi, L., Rispawati, \& Ismail. (2017). The effect of information technology on learning (A study on Civic and Pancasila Education students at Mataram University). Jurnal Pendidikan dan Pembelajaran, 24(2), 73-78.

Sumardi, L. \& Hanum, F. (2019). Social mobility and new form of social stratification: Study in Sasak tribe, Indonesia. International Journal of Scientific \& Technology Research, 8(10), 708-712.

Trilling, B., \& Fadel, C. (2009). $21^{\text {st }}$ century skills: Learning for life in our time. John Wiley \& Son.

Tyas, A. S. P. (2017). Self-actualization of pre-service English teachers prospective in $21^{\text {st }}$ century learning. Lingua Aplicata, 1(1), 1-16.

Wahyudiati, D., Sutrisno, H., \& Supiah, I. Y. L. (2019). Self-efficacy and attitudes toward chemistry of pre-service chemistry teachers: Gender and grades level 
perspective. International Journal of Scientific \& Technology Research, 8(09), 10411044.

Wahyudiati, D., Rohaeti, E., Irwanto, Wiyarsi, A., \& Sumardi, L. (2020). Attitudes toward chemistry, self-efficacy, and learning experiences of pre-service chemistry teachers: Grade level and gender differences. International Journal of Instruction, 13(1), 235-254.

Wijaya, E. Y., Sudjimat, D. A., \& Nyato, A. (2016). The transformation of $21^{\text {st }}$ century education as a demand for human resource development in the global era. Proceedings of the National Seminar on Mathematics Education, 1, 2528-259X. 